\title{
Upaya Meningkatkan Hasil Belajar Matematika Materi Bangun Ruang dengan Menggunakan Alat Peraga pada Kelas 9H di SMP Negeri 10 Jember Tahun Pelajaran 2018/2019
}

Author:
Sripurwantini ${ }^{1}$
Eny Zubaidah $^{2}$
Affiliation:
${ }^{1,2}$ SMP Negeri 10 Jember, East
Java, Indonesia
Corresponding author:
Sripurwantini,
mbakAntinsmpnegeri10jember
@ gmail.com
Dates:
Received: $18 / 6 / 2021$
Accepted: $20 / 11 / 2021$
Published: $30 / 11 / 2021$

\begin{abstract}
Abstrak. Penelitian ini bertujuan untuk mengetahui peningkatan hasil belajar menggunakan alat peraga pada siswa kelas 9H di SMP Negeri 10 Jember. Penelitian ini merupakan jenis penelitian tindakan kelas dengan model siklus iteratif dan berkesinambungan. Subjek dalam penelitian ini adalah siswa kelas 9H yang berjumlah 32 siswa yang terdiri dari 14 siswa perempuan dan 18 siswa laki-laki. Objek dalam penelitian ini adalah hasil belajar materi tata ruang sederhana. Instrumen yang digunakan adalah tes yang telah divalidasi oleh ahli, observasi sesuai standar isi, dan dokumentasi. Teknik analisis data dalam penelitian ini adalah analisis kualitatif dan analisis kuantitatif. Hasil penelitian ini menunjukkan bahwa terdapat peningkatan hasil belajar matematika siswa kelas $9 \mathrm{H}$ yang menggunakan media kongkrit berupa alat peraga spasial. Hal ini terlihat dari peningkatan nilai siswa pada bahan bangunan sebelum dan sesudah diberikan tindakan. Hasil penelitian diketahui bahwa rata-rata nilai seluruh siswa dan persentase ketuntasan siswa telah mencapai KKM, dari hasil tersebut dapat disimpulkan bahwa melalui media beton dapat meningkatkan hasil belajar matematika pada bahan bangunan sederhana untuk siswa kelas 9H di SMP Negeri 10 Jember pada tahun ajaran 2018/2019.

Kata Kunci: hasil belajar, bangun ruang, alat peraga
\end{abstract}

\begin{abstract}
This study aims to determine the improvement of learning outcomes using visual aids for $9 \mathrm{H}$ grade students at SMP Negeri 10 Jember. This research is a type of classroom action research with an iterative and continuous cycle model. The subjects in this study were students of class $9 \mathrm{H}$ totaling 32 students consisting of 14 female students and 18 male students. The object in this study is the result of learning simple spatial material. The instruments used are tests that have been validated by experts, observations according to content standards, and documentation. The data analysis technique in this research is qualitative analysis and quantitative analysis. The results of this study indicate that there is an increase in mathematics learning outcomes for students in grade $9 \mathrm{H}$ using concrete media in the form of spatial props. This can be seen from the increase in the value of students in building materials before and after being given action. The result is known that all students' average scores and the percentage of students' completeness have reached the KKM, from these results it can be concluded that through concrete media can improve mathematics learning outcomes in simple building materials for grade $9 H$ students at SMP Negeri 10 Jember in the 2018/2019 academic year.
\end{abstract}

Keywords: learning outcomes, solid geometry, teaching aids

\section{Copyright:}

This work is licensed under a Creative Commons Attribution-ShareAlike 4.0 International License.

Read online:

https://jurnal.unej.ac.id/index.php/JOMEAL/index or scan barcode beside.

How to cite this article:

Sripurwantini, S., \& Zubaidah, E. (2021). Upaya Meningkatkan Hasil Belajar Matematika Materi Bangun Ruang dengan Menggunakan Alat Peraga pada Kelas 9H di SMP Negeri 10 Jember Tahun Pelajaran 2018/2019. Journal of Mathematics Education and Learning, 1(3), 195-204. doi:10.19184/jomeal.v1i3.24811 


\section{Pendahuluan}

Hasil observasi dan informasi yang diberikan oleh guru di SMP Negeri 10 Jember kelas 9, terdapat permasalahan yang di hadapi oleh siswa yaitu rendahnya nilai ulangan harian, pernyataan tersebut di dasarkan pula pada ulangan harian siswa pada mata pelajaran matematika yang cukup rendah dan daya serap siswa secara klasikal masih dibawah standar minimum . Secara rinci dari 35 siswa kelas $9 \mathrm{H}$ yang mendapat nilai 80 adalah 5 siswa (14\%), yang mendapat nilai 70 sebanyak 7 siswa(20\%),yang mendapat nilai 60 sebanyak 8 siswa (22\%), dan yang mendapat nilai 50 kebawah sebanyak 15 siswa (44\%). Fakta ini menunjukan bahwa siswa belum mencapai ketuntasan belajar pada mata pelajaran matematika.

Prinsipnya, pengungkapan hasil belajar ideal meliputi segenap ranah psikologis yang berubah sebagai akibat pengalaman dan proses belajar siswa. Kunci pokok untuk memperoleh ukuran dan data hasil belajar siswa adalah mengetahui garis besar indicator dikaitkan dengan jenis prestasi yang hendak diungkapkan atau diukur. Indikator hasil belajar menurut Benjamin S. Bloom dengan Taxonomy of Education Objectives membagi tujuan pendidikan menjadi tiga ranah, yaitu ranah kognitif, afektif, psikomotorik. 7 Pengembangan dari masing-masing ranah dapat kita lihat pada table di bawah ini.

Tabel 1. Jenis dan Indikator Hasil Belajar

\begin{tabular}{|c|c|c|}
\hline No & Ranah & Indikator \\
\hline 1 & $\begin{array}{l}\text { Ranah kognitif } \\
\text { a. Pengetahuan (Knowledge) } \\
\text { b. Pemahaman } \\
\quad \text { (Comprehension) } \\
\text { c. Penerapan (Application) } \\
\text { d. Analisis (Analysis) } \\
\text { e. Menciptakan, membangun } \\
\text { (Synthesis) } \\
\text { f. Evaluasi (Evaluation) }\end{array}$ & $\begin{array}{l}\text { a. Mengidentifikasi, mendefinisikan, mendaftar, } \\
\text { mencocokkan, menetapkan, menyebutkan, melabel, } \\
\text { menggambarkan, memilih. } \\
\text { b. Menerjemahkan, merubah, menyamarkan, menguraikan } \\
\text { dengan kata-kata sendiri, menulis kembali, } \\
\text { merangkum, membedakan, menduga, mengambil } \\
\text { kesimpulan, menjelaskan } \\
\text { c. Menggunakan, mengoperasikan, menciptakan/membuat } \\
\text { perubahan, menyelesaikan, memperhitungkan, } \\
\text { menyiapkan, menentukan } \\
\text { d. Membedakan, memilih, membedakan, memisahkan, } \\
\text { membagi, mengidentifikasi, merinci, menganalisis, } \\
\text { membandingkan. } \\
\text { e. Membuat pola, merencanakan, menyusun, mengubah, } \\
\text { mengatur, menyimpulkan, menyusun, membangun, } \\
\text { merencanakan. } \\
\text { f. Menilai, membandingkan, membenarkan, mengkritik, } \\
\text { menjelaskan, menafsirkan, mersngkum, mengevaluasi. }\end{array}$ \\
\hline 2 & $\begin{array}{l}\text { Ranah Afektif } \\
\text { a. Penerimaan (Receiving) } \\
\text { b. Menjawab/me nanggapi } \\
\quad \text { (Responding) } \\
\text { c. Penilaian (Valuing) } \\
\text { d. Organisasi (Organization) } \\
\text { e. Menentukan ciri-ciri nilai } \\
\text { (Characterizat ion by a } \\
\text { value or value complex) }\end{array}$ & $\begin{array}{l}\text { a. membagikan, bergabung, mengikuti, mengemukakan, } \\
\text { membaca, belajar, bekerja, menerima, melakukan, } \\
\text { mendebat } \\
\text { b. Mempertahankan, mengubah, menggabungkan, } \\
\text { mempersatukan, mendengarkan, mempengaruhi, } \\
\text { mengikuti, memodifikasi, menghubungkan, } \\
\text { menyatukan } \\
\text { c. Mengikuti, menghubungkan, memutuskan, menyajikan, } \\
\text { menggunakan, menguji, menanyai, menegaskan, } \\
\text { mengemukakan, memecahkan, mempengaruhi, } \\
\text { menunjukkan. }\end{array}$ \\
\hline
\end{tabular}




\begin{tabular}{|c|c|c|}
\hline No & Ranah & Indikator \\
\hline & & $\begin{array}{l}\text { d. Membawa, mendengar, memberi reaksi, } \\
\text { memindahkan, mengerti, berjalan, memanjat, } \\
\text { melompat, memegang, berdiri, berlari. } \\
\text { e. Melatih, membangun, membongkar, merubah, } \\
\text { melompat, merapikan, memainkan, mengikuti, } \\
\text { menggunakan, menggerakkan. } \\
\text { f. Bermain, menghubungkan, mengaitkan, menerima, } \\
\text { menguraikan, mempertimbangkan, membungkus, } \\
\text { menggerakkan, berenang, memperbaiki, menulis. } \\
\text { g. Menciptakan, menemukan, membangun, menggunakan, } \\
\text { memainkan, menunjukkan, melakukan, membuat, } \\
\text { menyusun, membagikan, bergabung, mengikuti, } \\
\text { mengemukakan, membaca, belajar, bekerja, menerima, } \\
\text { melakukan, mendebat } \\
\text { h. Mempertahankan, mengubah, menggabungkan, } \\
\text { mempersatukan, mendengarkan, mempengaruhi, } \\
\text { mengikuti, memodifikasi, menghubungkan, } \\
\text { menyatukan } \\
\text { i. Mengikuti, menghubungkan, memutuskan, menyajikan, } \\
\text { menggunakan, menguji, menanyai, menegaskan, } \\
\text { mengemukakan, memecahkan, mempengaruhi, } \\
\text { menunjukkan. }\end{array}$ \\
\hline 3 & $\begin{array}{l}\text { Ranah psikomotor } \\
\text { a. Gerakan Pokok } \\
\text { (Fundamental Movement) } \\
\text { b. Gerakan Umum (Generic } \\
\text { Movement) } \\
\text { c. Gerakan Ordinat } \\
\text { (Ordinative Movement) } \\
\text { d. Gerakan Kreativ (Creative } \\
\text { Movement) }\end{array}$ & $\begin{array}{l}\text { a. Membawa, mendengar, memberi reaksi, } \\
\text { memindahkan, mengerti, berjalan, memanjat, } \\
\text { melompat, memegang, berdiri, berlari. } \\
\text { b. Melatih, membangun, membongkar, merubah, } \\
\text { melompat, merapikan, memainkan, mengikuti, } \\
\text { menggunakan, menggerakkan } \\
\text { c. Bermain, menghubungkan, mengaitkan, menerima, } \\
\text { menguraikan, mempertimbangkan, membungkus, } \\
\text { menggerakkan, berenang, memperbaiki, menulis } \\
\text { d. Menciptakan, menemukan, membangun, menggunakan, } \\
\text { memainkan, menunjukkan, melakukan, membuat, } \\
\text { menyusun }\end{array}$ \\
\hline
\end{tabular}

Salah satu lingkungan belajar yang paling dominan mempengaruhi hasil belajar di sekolah adalah kualitas pengajaran. Kualitas pengajaran adalah tinggi rendahnya atau efektif tidaknya proses belajar mengajar dalam mencapai tujuan pengajaran. Menurut Hammil salah satu bentuk kesulitan belajar adalah berhitung. Kesulitan berhitung atau metematika (dyscalculia learning) merupakan suatu gangguan perkembangan kemampuan aritmatika atau keterampilan matematika yang jelas mempengaruhi pencapaian prestasi akademika atau mempengaruhi kehidupan sehari-hari anak.

Kesulitan belajar tidak selalu disebabkan karena faktor intelegensi yang rendah (kelainan mental), akan tetapi dapat juga disebabkan oleh faktor-faktor non-intelegensi. Kolb (1949) mendefinisikan belajar metematika sebagai proses memperoleh pengetahuan yang diciptakan atau dilakukan oleh siswa itu sendiri melalui transformasi pengalaman individu siswa. Pendapat Kolb ini 
intinya menekankan bahwa belajar siswa harus diberi kesempatan seluas-luasnya mengkonstruksi sendiri pengetahuan yang dipelajari dan siswa harus didorong untuk aktif berinteraksi dengan lingkungan belajarnya sehingga dapat memperoleh pemahaman yang lebih tinggi dari sebelumnya. Fungsi pembelajaran matematika menurut Suherman (2003:55) adalah sebagai berikut:

1. Sebagai Alat

Melalui matematika siswa dapat memahami dan menyampaikansuatu informasi misalnya melalui persamaan atau tabel-tabel dalam model matematika

2. Sebagai Pola Pikir

Belajar matematika merupakan pembentukan pola pikir dalam pemahaman suatu pengertian. Pola pikir yang dikembangkan adalah pola pikir deduktif dan induktif.

3. Sebagai Ilmu

Matematika selalu mencari kebenaran dan bersedia meralat kebenaran yang sementara diterima, bila ditemukan penemuan baru sepanjang mengikuti pola pikir yang sah.

\section{Materi Bangun Ruang}

Bangun ruang adalah bagian ruang yang dibatasi oleh himpunan titik-titik yang terdapat pada seluruh permukaan bangun tersebut. Permukaan bangun itu disebut sisi. Bangun ruang dikenal istilah sisi, rusuk, dan titik sudut. Sisi adalah bidang atau permukaan yang membatasi bangun ruang. Rusuk adalah garis yang merupakan pertemuan dari dua sisi bangun ruang. Titik sudut adalah titik pertemuan dari tiga buah rusuk pada bangun ruang.

Macam - macam bangun ruang yaitu:

Kubus adalah sebuah benda ruang yang dibatasi oleh enam buah persegi yang berukuran sama. Sifat-sifat kubus adalah sebagai berikut:

1) Memiliki 6 sisi yang ukuran dan modelnya sama. Sisi-sisi kubus tersebut berbentuk persegi (bujursangkar) yang berukuran sama.

2) Memiliki 12 rusuk yang ukurannya sama. Rusuk-rusuk kubus tersebut mempunyai panjang yang sama.

3) Memiliki 8 buah sudut yang sama besar.

Balok adalah sebuah benda ruang yang dibatasi oleh tiga pasang (enambuah) persegipanjang dimana setiap pasang persegi panjang saling sejajar (berhadapan) dan berukuran sama. Sifat - sifat balok adalah sebagai berikut:

1) Memiliki 4 sisi berbentu kpersegi panjang.

2) Memiliki 2 sisi yang bentuknya sama.

3) Memiliki 4 rusuk yang ukurannya sama

Tabung adalah bangun ruang tabung mempunyai 3 buah sisi, yaitu sisi lengkung, sisi atas, dan sisi bawah. Tabung mempunyai 2 buah rusuk, tetapi tidak mempunyai titik sudut. Kerucut adalah bangun ruang kerucut mempunyai dua buah sisi, yaitu sisi alas dan sisi lengkung. Kerucut hanya mempunyai sebuah rusuk dan sebuah titik sudut yang biasa disebut titik puncak.

\section{Model Perolehan Konsep (Concept Attainment)}

1. Pengertian Model Perolehan Konsep (Concept Attainment)

Perolehan konsep merupakan suatu pencarian dan pendataan ciri- ciri untuk membedakan apakah sesuatu termasuk konsep tertentu atau tidak . 
Perolehan konsep menurut Ausubel (1968), diperoleh dengan dua cara, yaitu konsep formasi dan konsep asimilasi. Konsep formasi terutama merupakan bentuk peroleh konsep sebelum peserta didik masuk sekolah. Konsep formasi dapat disamakan dengan belajar konsep kongkrit menurut Gagne (1977). Konsep asimilasi merupakan cara-cara untuk memperoleh konsep selama dan sesudah sekolah.

Menurut Bruner, Goodnow, dan Austin Perolehan konsep (concept attainment) merupakan proses mencari dan mendaftar sifat-sifat yang dapat digunakan untuk membedakan contoh-contoh yang tepat dengan contoh-contoh yang tidak tepat dari berbagai kategori. Model Perolehan Konsep adalah proses mengidentifikasi dan mendefinisikan konsep dengan jalan menemukan atributnya yang paling esensial sesuai dengan pengertian konsep yang dipelajari. Atribut tersebut harus membedakan contoh konsep itu dengan yang bukan contoh konsep. Oleh karena itu model Perolehan Konsep (Concept Attainment Model) adalah model pembelajaran induktif yang dirancang membantu siswa segala umur untuk belajar konsep sekaligus mempraktikkan keterampilan berpikir analitis.

Bruner mengusulkan teorinya yang disebut free discovery learning. Menurut teori ini, "proses belajar akan berjalan dengan baik dan kreatif, jika guru member kesempatan kepada siswa untuk menemukan suatu aturan (termasuk konsep, teori, definisi, dan sebagainya) melalui contoh-contoh yang menggambarkan (mewakili) aturan yang menjadi sumbernya”.

Dengan kata lain, siswa dibimbing secara induktif untuk memahami suatu kebenaran umum. Jadi Model Pembelajaran Perolehan Konsep adalah model pembelajaran yang dirancang untuk menata, atau menyusun data sehingga konsep-konsep penting dapat dipelajari secara tepat dan efisien, dimana model ini memiliki pandangan bahwa, para siswa tidak hanya dituntut untuk mampu membentuk konsep melalui proses pengklasifikasian data, akan tetapi mereka juga harus dapat membentuk susunan konsep dengan kemampuannya sendiri.Model Perolehan Konsep (Concept Attainment) bertujuan Untuk belajar konsep sekaligus mempraktikkan keterampilan berpikir analitis (Klausmeier, 1985:Tennyson \& Cocchiarella, 1986).

Dalam pendidikan dan pengajaran, proses kegiatan belajar belajar mengajar sangat berpengaruh pada hasil belajar mengajar nantinya, misalnya kegiatan belajar yang kurang maksimal akan melahirkan hasil belajar yang kurang maksimal juga. Sebaliknya kegiatan belajar mengajar yang maksimal akan melahirkan hasil belajar yang maksimal juga, tidak maksimalnya sebuah kegiatan belajar mengajar dapat disebabkan dari guru atau dari metode pembelajarannya.

Melalui model pembelajaran perolehan konsep (Concept Attainment), siswa diharapkan mampu membentuk konsep melalui proses pengklasifikasian data, serta membentuk susunan konsep dengan kemampuannya sendiri, sehingga pemahaman konsep matematika siswa dalam pembelajaran menjadi lebih baik dibandingkan pembelajaran konvensional.

Tindakan perbaikan pembelajaran mata pelajaran matematika, khususnya materi pokok membuat suatu karya / model, misalnya periskop / lensa dari bahan sederhana dengan menerapkan sifat-sifat cahaya ini dilaksanakan dalam 2 siklus.

Rancangan dalam penelitian ini mengikuti alur tindakan yang diutarakan Suharsimi Arikunto (2006:16) sebagai berikut:

1. Perencanaan (planning)

2. Pelaksanaan (acting)

3. Pengamatan (observing) 


\section{Refleksi (reflecting)}

\section{Hasil Penelitian dan Pembahasan}

\section{A. Deskripsi Hasil Penelitian Per Siklus}

\section{Deskripsi hasil penelitian siklus 1}

Pada siklus pertama ini yang dilakukan dalam pelaksanaan perbaikan pembelajaran di kelas V pada mata pelajaran matematika dengan menggunakan metode alat peraga pada siswa. Metode penggunaan alat peraga secara kelompok pada siswa ini bertujuan agar siswa dapat meningkatkan hasil belajar dengan membuat alat peraga periskop, sehingga siswa dapat langsung menggunakan alat dengan objek yang nyata. Tetapi dalam penggunaan metode tersebut masih mempunyai kekurangan, karena siswa hanya aktif dan kreatif dalam membuat alat peraga periskop saja sedangkan pada saat diminta mempraktekkan / mendemostrasikan alat tersebut tidak semua bisa memperagakan. Oleh karena itu setelah di amati ternyata dari 35 siswa yang masih belum bisa mendemostrasikan alat peraga periskop adalah 12 siswa. Nilai kemampuan awal diperoleh dari mulai tes pada kompetensi yang sama dengan materi yang telah diteliti.

Dari penjelasan diatas dapat dilihat dari tabel di bawah ini bahwa setelah dilakukan perbaikan pembelajaran dengan metode alat peraga secara kelompok pada siklus pertama ternyata belum mengalami perkembangan yang optimal dari kegiatan awal pembelajaran. Sehingga pada perbaikan pembelajaran siklus pertama dapat diperoleh hasil pengolahan dalam data bentuk table dan grafik di bawah ini :

Tabel 2. Tabel Nilai Siklus I

\begin{tabular}{|c|c|c|}
\hline \multirow{2}{*}{ Nilai } & \multicolumn{2}{|c|}{ Jumlah Siwa } \\
\cline { 2 - 3 } & Awal & Siklus I \\
\hline 10 & - & - \\
20 & - & - \\
30 & 2 & 2 \\
40 & 3 & 3 \\
50 & 10 & 3 \\
60 & 8 & 5 \\
70 & 7 & 9 \\
80 & 5 & 8 \\
90 & - & 5 \\
100 & - & \\
\hline Jumlah & $\mathbf{3 5}$ & $\mathbf{3 5}$ \\
\hline
\end{tabular}

Sementara itu, pengamatan yang dilakukan secara intensif oleh teman sejawat selama proses pelaksanaan perbaikan pembelajaran pada siklus 1 , menghasilkan data penelitian sebagai berikut:

Tabel 3. Data Hasil Observasi Teman Sejawat tentang Kualitas Alat Peraga Hasil Rancangan Guru pada Siklus 1

\begin{tabular}{|c|l|c|}
\hline No. & \multicolumn{1}{|c|}{ Aspek yang di amati } & Komentar \\
\hline 1. & Ukuran & Baik \\
\hline 2. & Kejelasan & Kurang \\
\hline 3. & Kelengkapan & Baik \\
\hline 4. & Warna & Baik \\
\hline
\end{tabular}


Tabel 4. Data Hasil Observasi Teman Sejawat tentang Kemampuan Guru dalam Menggunakan Alat

\begin{tabular}{|c|l|c|}
\hline \multicolumn{3}{|c|}{ Peraga } \\
\hline No. & \multicolumn{1}{|c|}{ Aspek yang di amati } & Komentar \\
\hline 1. & Keterampilan Guru & Baik \\
\hline 2. & Efektifitas & Baik \\
\hline
\end{tabular}

\section{Diskripsi hasil penelitian siklus 2}

Berdasarkan pengamatan yang telah dilakukan dalam proses perbaikan pembelajaran pada siklus pertama belum menunjukkan hasil yang optimal karena masih ada 13 anak yang belum dapat menyelesaikan tugasdengan maksima. Sehingga perlu dilakukan rencana perbaikan pembelajaran pada siklus 2 agar dapat menunjukkan hasil yang lebih optimal. Pada siklus 2 ini pembelajaran dilakukan dengan cara diskusi dengan teman sebangku tentang alat peraga periskop yang telah dibuat.

Semua ini dapat dilihat dari data observasi dan tes tulis, ternyata banyak kemajuan yang optimal. Terbukti 4 dari 35 anak yang tidak dapat mendemostrasikan alat peraga periskop yang telah dibuat. Sehingga dapat diperoleh hasil pengolahan data pada proses perbaikan pembelajarn siklus 2 ini dalam bentuk table dan grafik di bawah ini :

Tabel 5. Nilai Siklus II

\begin{tabular}{|c|c|c|}
\hline \multirow{2}{*}{ Nilai } & \multicolumn{2}{|c|}{ Jumlah Siswa } \\
\cline { 2 - 3 } & Siklus I & Siklus II \\
\hline 10 & - & - \\
20 & - & - \\
30 & 2 & - \\
40 & 3 & - \\
50 & 3 & 2 \\
60 & 5 & 2 \\
70 & 9 & 15 \\
80 & 8 & 9 \\
90 & 5 & 6 \\
100 & - & 1 \\
\hline Jumlah & $\mathbf{3 5}$ & $\mathbf{3 5}$ \\
siswa & & \\
\hline
\end{tabular}

\section{B. Pembahasan Hasil Penelitian Per Siklus}

\section{Pembahasan hasil penelitian siklus 1}

Melalui hasil penelitian pada siklus pertama menunjukkan bahwa metode penggunaan alat peraga periskop dengan pembentukan kelompok belum mempunyai pengaruh positif dalam meningkatkan hasil belajar siswa dalam mengikuti pelajaran matematika. Hal tersebut terbukti pada nilai hasil belajar siswa yang masih belum meningkat. Dari jumlah siswa keseluruhan (35 siswa) yang dapat mendemostrasikan / mempraktekan alat peraga periskop secara maksimal hanya sebagian anak saja ( 22 siswa).

\section{Pembahasan hasil penelitian siklus 2}

sMelalui hasil penelitian yang dilakukan pada proses perbaikan siklus kedua ini, sudah menunjukkan suatu keberhasilan. Hal ini dapat dilihat semakin tingginya hasil pemahaman 
siswa terhadap materi pelajaran matematika yang disampikan oleh guru. Dimana hasil belajar siswa meningkat dari siklus I $(68,6 \%)$ dan siklus II $(88,6 \%)$.

Berdasarkan hasil pengamatan terhadap masalah-masalah selama pelaksanaan proses pembelajaran pada siklus I dari hasil tes akhir, dan catatan lapangan diperoleh hasil sebagai berikut:

1. Prestasi belajar siswa berdasarkan hasil tes siklus I menunjukkan bahwa prestasi belajar siswa belum bisa memenuhi ketuntasan belajar yang diharapkan

2. Siswa kurang aktif menyampaikan pendapat dalam diskusi kelompok

3. Dalam menyelesaikan soal kuis maupun tes evaluasi masih ada siswa yang contekan dengan temannya.

Masalah-masalah di atas timbul disebabkan oleh faktor-faktor antara lain:

1. Siswa belum terbiasa belajar kelompok yang anggotanya dibentuk secara heterogen

2. Siswa masih kurang percaya diri dengan kemampuan yang dimilikinya sehingga mereka masih menggantungkan pada temannya dalam menyelesaikan soal-soal tes

Ditinjau dari masalah-masalah dan faktor-faktor penyebabnya, maka dilakukan tindakantindakan untuk mengatasi:

1. Guru harus menjelaskan kemudahan dan manfaat yang diperoleh ketika belajar dalam kelompok yang dibentuk secara heterogen.

2. Guru harus menjelaskan pada siswa bahwa semua manusia itu sama, maka kita tidak boleh memilih-milih teman, dan juga setiap manusia mempunyai kelebihan kelebihan sendiri-sendiri.

3. Guru sangat perlu memperhatikan dan memberikan pembinaan ekstra pada siswa agar siswa mempunyai semangat untuk belajar sehingga prestasinya bisa meningkat.

Dari uraian di atas, maka secara umum pada siklus I belum menunjukkan adanya peningkatan partisipasi aktif dari siswa, belum adanya peningkatan prestasi belajar siswa karena ketuntasan belajar siswa masih belum memenuhi keinginan yang diharapkan, serta belum adanya keberhasilan guru dalam pembelajaran.

Oleh kareana itu perlu dilanjutka pada siklus II agar prestasi belajar matematika siswa bisa ditingkatkan sesuaia dengan harapan.

Selanjutnya setelah merefleksi hasil sikus I, peneliti mengkonsultasikan dengan guru bidang studi matematika kelas VIII untuk melanjutkan ke siklus II. Setelah memperoleh persetujuan peneliti langsung menyusun rencana pelaksanaan siklus II.

\section{Temuan Penelitian}

Beberapa temuan yang diperoleh pada pelaksanaan penelitian ini adalah:

1. Siswa merasa senang dengan belajar kelompok, karena dengan belajar kelompok mereka dapat saling bertukar pikiran/pendapat dengan teman.

2. Pelaksanaan pembelajaran membuat siswa yang semula pasif menjadi aktif dalam kegiatan kelompok. Menurut siswa dengan belajar, mereka dapat saling bertanya jika mengalami kesulitan baik kepada guru maupun teman.

3. Siswa lebih mudah memahami materi dengan adanya alat peraga dalam belajar untuk menjadi kelompok asal yang terbaik. 
4. Mampu mentransfer pengalaman belajar pada pembelajaran Sistem Persamaan Linier Dua Variabel (SPLDV), sehingga mereka lebih mudah menemukan dan memahami.

5. Kegiatan pada materi bangun ruang ini mendapat respon yang positif dari siswa.

Berdasarkan keaktifan siswa dalam kegiatan yang telah dilakukan menun jukkan adanya peningkatan dari tiap tindakan. Perubahan positif pada keaktifan siswa berdampak pula pada prestasi belajar dan ketuntasan belajar. Hal ini dapat dilihat pada tabel 6 .

Tabel 6. Rata-rata hasil dan ketuntasan belajar siswa

\begin{tabular}{|l|c|c|c|}
\hline \multicolumn{1}{|c|}{ Kriteria } & Siklus I & Siklus II & Peningkatan \\
\hline Rata - rata hasil belajar siswa & 83.94 & 85 & 1.05 \\
\hline Ketuntasan belajar siswa & $89.47 \%$ & $92.10 \%$ & $2.63 \%$ \\
\hline
\end{tabular}

Dari tabel di atas dapat diketahui bahwa ada peningkatan yang signifikan pada rata-rata hasil belajar siswa dari Siklus I ke siklus II, yaitu sebesar 1.05 begitu pula pada ketuntasan belajar matematika terjadi peningkatan sebesar $2.63 \%$ dari siklus I ke siklus II. Dengan demikian pada siklus II telah mencapai target awal meningkatkan hasil prestasi belajar matematika. Hal ini sesuai dengan pendapat Edward, bahwa unggul dalam meningkatkan hasil akademik bila dibandingkan dengan pengalaman belajar individu/kompetitif'. Karena kelompok yang terdiri dari dari empat orang terbukti sangat efektif. Sedangkan Sudjana mengemukakan, beberapa siswa dihimpun dalam satu kelompok dapat terdiri dari 4-6 orang siswa. Jumlah yang paling tepat menurut hasil penelitian Slavin adalah hal itu dikarenakan kelompok yang beranggotakan 4-6 orang siswa lebih sepaham dalam menyelesaikan suatu permasalahan dibandingkan dengan kelompok yang beranggotakan 2-4 orang.

\section{Kesimpulan}

Dari hasil pembelajaran yang telah dilakukan selama dua siklus dan berdasarkan seluruh pembahasan serta analisis yang telah dilakukan dapat disimpulkan sebagai berikut: "Upaya meningkatkan hasil belajar matematika materi bangun ruang dengan menggunakan alat peraga pada kelas 9 H di SMP Negeri 10 Jember tahun 2018/2019 ini terbukti dari hasil pengamatan bahwa hasil belajar meningkat dari siklus I dan siklus II yaitu masing-masing: siklus I $(68,6 \%)$ dan siklus II $(88,6 \%)$.

\section{Daftar Pustaka}

Abidin, Z. K, dkk. (1981). Media Pendidikan IV, Pemilihan dan Penggunaan Media dalam Proses Belajar mengajar. Penataran-Loka Karya Tahap II. Jakarta: P3G Depdikbud.

Arikunto, S. (2002). Prosedur Penelitian. Jakarta: Rineka Cipta (2005). Manajemen Pendidikan. Jakarta: Rineka Cipta (2006). Penelitian Tindakan Kelas. Jakarta: Bumi Aksara. (2009). Prosedur Penelitian. Jakarta: Rineka

Azhar, A. (2006). Media Pembelajaran. Jakarta: Raja Grafindo Persada

Baharuddin \& Wahyuni, N. (2010). Teori Belajar dan Pembelajaran. Yogyakarta: Ar-Ruzz Media. Depdiknas. (2006). Standar Kompetensi Mata Pelajaran Matematika. Jakarta: Depdiknas Dimyati dan Mudjiono. (2006). Belajar dan Pembelajaran. Jakarta: PT. Rineka Cipta 
Dimyati dan Mudjiono. (2002). Belajar dan Pembelajaran. Jakarta: PT. Rineka

Fathurrohman dan Wuryandani, W. (2011). Pembelajaran PKn di Sekolah Dasar. Yogyakarta:

Nuha \& Idris. (2010). Strategi \& Metode Pengajaran. Yogyakarta: Ar-Ruszz Media.

Marsigit. (2003). Metodologi pembelajaran matematika. Disampaikan pada kunjungan guru-guru SD wilayah Binaan III Kecamatan Kemayoran Jakarta Pusat di FMIPA UNY, pada sabtu, 4 Januari 2003.

Muchtar A. K. (1997). Pendidikan Matematika I. Malang: Depdikbud.

Mulyono, A. (2003). Pendidikan Bagi Anak Berkesulitan Belajar. Jakarta: Rineka Cipta

Hamalik, O. (1985). Media Pendidikan. Bandung: Alumni

- (1999). Kurikulum dan Pembelajaran. Jakarta: PT. Bumi Aksara

-. (2007). Kurikulum dan Pembelajaran. Jakarta: PT. Bumi Aksara.

- (2010). Kurikulum dan Pembelajaran. Jakarta: PT. Bumi Aksara.

Mudyahardjo, R. (2006). Pengantar Pendidikan. Jakarta: Raja Grafindo Persada

Izzaty, R.E dkk. (2008). Perkembangan Peserta Didik. Yogyakarta: UNY Press.

Pitajeng. (2006). Pembelajaran Matematika yang Menyenangkan. Jakarta: Depdiknas.

Purwanto. (2010). Evaluasi Hasil Belajar. Yogyakarta: Pustaka Pelajar.

Slavin, R. E. (2005). Cooperative Learning. Bandung: Penerbit Nusa Media.

Ruseffendi. (1992). Pendidikan Matematika. Jakarta: Depdikbud.

Rusyan, T. (1992). Pendekatan Dalam Proses Belajar Mengajar. Bandung: Remadja Karya CV Wijaya

Sadiman, dkk. (1984). Media Pendidikan, Pengertian, Pengembangan, dan Pemanfaatannya. Jakarta: PT. Raja Grafindo Persada

Siswoyo, C.D, dkk. (2008). Ilmu Pendidikan. Yogyakarta: UNY Press

Subarinah, S. (2006). Inovasi Pembelajaran Matematika. Jakarta: Depdiknas

Sugihartono, dkk. (2007). Psikologi Pendidikan.Yogyakarta: UNY Press

Sugiyono. (2008). Metode Penelitian. Jakarta: Gramedia

Kusumah dan Dwitagama, D. (2010). Mengenal Penelitian Tindakan Kelas. Jakarta: PT. Indeks

Sanjaya, W. (2011). Penelitian Tindakan Kelas. Jakarta:

Wibowo, B dan Farida Mukti. (1992). Media Pendidikan. Jakarta: Depdikbud P2TK 